\title{
Regionális politikai és területi kormányzási ciklusok Közép- és Kelet-Európában
}

\section{Cycles of regional policy and territorial governance in Central and Eastern Europe}

\author{
PÁLNÉ KOVÁCS ILONA, MEZEI CECÍLIA
}

\begin{abstract}
PÁLNÉ KOVÁCS Ilona: kutatóprofesszor, MTA Közgazdaság- és Regionális Tudományi Kutatóközpont, Regionális Kutatások Intézete; 7621 Pécs, Papnövelde u. 22.; egyetemi tanár, Pécsi Tudományegyetem; 7622 Pécs, Ifjúság útja 6.; palne@rkk.hu

MEZEI Cecília: tudományos munkatárs, MTA Közgazdaság- és Regionális Tudományi Kutatóközpont, Regionális Kutatások Intézete; 7621 Pécs, Papnövelde u. 22.; egyetemi docens, Kaposvári Egyetem; 7400 Kaposvár, Guba Sándor u. 40.; mezeic@rkk.hu
\end{abstract}

KULCSSZAVAK: regionális fejlesztéspolitika; decentralizáció; regionalizmus; uniós támogatások menedzsmentje

ABSZTRAKT: Horváth Gyula meggyőződése volt, hogy a regionalizált kormányzati rendszerű országok sikeresebbek a gazdasági versenyben és hatékonyabbak a társadalmi, területi felzárkóztatásban is. A mintegy három évtizede Nyugat-Európában végrehajtott regionalizációs reformok alátámasztották ezt a véleményt. Nem volt véletlen tehát, hogy a közép- és kelet-európai csatlakozó országok számára is mintául szolgáltak a sikeres példák az uniós kohéziós politikához való alkalmazkodási stratégiák formálása során.

A tanulmány azt a kérdést igyekszik körbejárni, vajon milyen tényezők okozták a közép- és kelet-európai országok regionális reformjainak kudarcát vagy elmaradását. A szerzők a helyi és középszintü önkormányzati rendszerek és a kohéziós alapok menedzsmentjének kronológiába rendezett összehasonlító elemzésével rámutatnak arra, hogy a sikeres regionális reformokhoz rendkívül összetett feltételrendszer szükséges, pusztán az intézményi változások nem elegendőek a regionális decentralizációhoz, viszont az intézményi változások elmaradása önmagában nem ad magyarázatot a regionális felzárkózás elmaradására.

Ilona PÁLNÉ KOVÁCS: research professor, Institute for Regional Studies, Centre for Economic and Regional Studies, Hungarian Academy of Sciences; Papnövelde u. 22., H-7621 Pécs, Hungary; professor, University of Pécs; Ifjúság útja 6., H-7622 Pécs, Hungary; palne@rkk.hu

Cecilia MEZEI: research fellow, head of department, Institute for Regional Studies, Centre for Economic and Regional Studies, Hungarian Academy of Sciences; Papnövelde u. 22., H-7621 Pécs, Hungary; associate professor, University of Kaposvár; Guba Sándor u. 40., H-7400, Kaposvár, Hungary;mezeic@rkk.hu

KEYWORDS: regional development; decentralization; regionalism; management of EU cohesion and structural funds

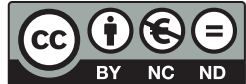


ABSTRACT: The paper is a tribute to Gyula Horvath's work. Gyula Horvath was convinced that countries with regionalized government systems are more effective in terms of economic competitiveness and more successful in their social and territorial convergence. The regionalization reforms implemented in Western Europe about three decades ago also support this view.

It was no coincidence, then, that these successful examples served as models for the acceding Central and Eastern European countries in their adjustment to EU cohesion policy. This study tries to describe the causes behind these latter reforms' failures and fall-backs. The authors, by conducting a chronologically ordered comparative analysis of territorial governments and Cohesion Funds management, show that the success of regional reforms required an extremely complex system of conditions. The institutional changes were not sufficient for regional decentralization, but neither the lack of institutional changes alone explains the failure of regional convergence. Gyula Horvath was right to argue that the effectiveness of regional development and cohesion policy considerably depends on institutional and governance adaptability. Unfortunately, he was wrong in assuming that the new democracies of Central and Eastern Europe will be able to achieve this in a short time. The governmental and political culture of the countries successful in their territorial governance favors modernization and consciously prepares its institutional system for continuous change. Other countries, on the other hand, which are unprepared for government modernization tend to track an external sample and, therefore, produce hectic and often unsustainable changes in their territorial reforms.

\section{Bevezetés}

„Governance matters” - fogalmaztak a Világbank szakértői, amikor közreadták azokat a 150 ország adataira épülő, hat tényezőcsoportba sürített, mintegy 300 indikátort alkalmazó elemzéseket, amelyek közvetlen összefüggést kerestek a kormányzás minősége és a fejlődés között (Kaufmann, Kraay, Zoido-Lobatón 1999). Az elemzések szerint a jobban kormányzott országok gazdasági fejlettsége, a népesség jövedelme, egészségi és műveltségi jellemzői is jobbak, bár természetesen nem adnak kizárólagos magyarázatot a fejlődésre. A módszertan folyamatos továbbfejlesztésével (Kaufmann, Kraay, Mastruzzi 2009, 2010) időről időre közreadott jelentések, a világszintű kormányzási indikátorok (WGI) ezt az összefüggést alátámasztják, jelenleg már több mint 200 országra vonatkoztatva.

A jó kormányzással szembeni „elvárások”, indikátorok között a decentralizáció csak közvetve jelent meg, az egyéb demokratikus kormányzási alapértékekhez képest (részvétel, átláthatóság, elszámoltathatóság stb.) változó erősséggel és tartalommal, lényegében azt felismerve, hogy szinte lehetetlen valamiféle decentralizációs standardot megállapítani (Pálné Kovács 2014). A nemzetközi szervezetek a decentralizációt alapos mérlegelés nélkül ajánlották számtalan ország számára (Hutchcroft 2001), s a nyolcvanas évek közepétől a világ mintegy hatvan országában zajlottak decentralizációs reformok (Crook, Manor 2000). Az „alkalmassá tétel” kulcskérdése a decentralizációnak, miután a kudarcok, a várt eredmények elmaradása legtöbbször azzal magyarázható, hogy a decentralizáció kedvezményezettjei oldalán hiányzik az adminisztratív, szervezeti, pénzügyi kapacitás az újabb feladatok fogadásához (Litvack, Ahmad, Bird 1998; Manor 1999; Stead, Nadin 2011). 
A jó kormányzás hatékonysági dimenzióinak elemezésénél is felmerül a kérdés, vajon a kormányzási teljesítményben mennyire játszik szerepet a decentralizáció. A gazdaságfejlesztés, a regionális különbségek kezelése vajon összefügg-e a kormányzás térbeli szerkezetével? Az ezzel kapcsolatos kutatási eredmények ambivalensek annak ellenére, hogy a decentralizáció mértékének és hatásának mérése a tudományos és szakpolitikai elemzésekben egyre gyakoribb. Az egyik leggyakrabban citált és használt megközelítést Treisman dolgozta ki (2002). Hooghe és társai más módszertant alkalmazva, az 1950-2006 közötti adatokra támaszkodva szintén arra jutottak, hogy a decentralizáltabb országok általában jobban kormányzottak, s egyben jobb gazdasági, jóléti teljesítményt nyújtanak. Felhívták azonban a figyelmet arra, hogy a decentralizáció sokszínü jelenség, számtalan típusa van, a valóságban nagyon eltérő következményekkel (Hooghe, Marks, Schakel 2008). A kormányzási rendszerek szerkezeti átalakításának tartós trendje a decentralizáció volt ugyan, de azt feltételezték, hogy a turbulens szerkezeti reformok kora lassan lejár, különösen a fejlett demokráciákban (Hooghe, Marks, Schakel 2008, 178.). Ez a prognózis nem számolt a gazdasági válsággal. Az Európai Települések és Régiók Tanácsa a válság utáni reformokat áttekintve azt állapította meg, hogy szinte minden európai állam jelentős reformokat hajtott végre, gyakran centralizáció következett be. A decentralizáció kétségtelenül válaszúton van (CEMR 2013), annak ellenére, hogy természetesen a válságkezelés nem feltétlenül tesz szükségessé centralizációt, sőt, van példa arra, hogy a decentralizációt vetették be a fiskális problémák megoldására.

A decentralizáció lényegében normatív igénye évtizedeken keresztül megjelent a kormányzással foglalkozó nemzetközi dokumentumokban is. Az Európa Tanács égisze alatt 1985-ben megszületett helyi önkormányzati charta még általános érvénnyel szimbolizálta az önkormányzatiság demokratikus előnyeit. A 2001-ben született európai kormányzásról szóló fehér könyvben kívánatosnak tartották a városok, régiók bevonását a döntéshozásba a részvétel, a nyitottság, a nagyobb rugalmasság, a demokrácia és a policykoherencia érdekében. A 2008-ban megjelent, a Világbank égisze alatt készült első világméretű értékelésben, az ún. Gold-jelentésben úgy fogalmaznak, hogy a kétségtelen konvergencia a decentralizáció terén a globalizáció következménye, amely hozzájárult a demokrácia megerősödéséhez (Marcou 2008).

Az Európai Unió dokumentumai az integráció szemszögéből közelítenek a decentralizációhoz. Még hangsúlyosabbá válik a decentralizáció és a regionalizmus értéke a szubszidiaritás elvének az európai integrációs szerződésekbe foglalása nyomán, majd a többszintű kormányzásról szóló fehér könyv megfogalmazásával. Bár az EU hivatalos narratívájában és dokumentumaiban a többszintű kormányzás bázisát jelentő szubszidiaritás elve megkérdőjelezhetetlen, mégis érzékelhető az elvvel, s ha úgy tetszik, a régiók szerepével kapcsolatban az elbizonytalanodás. A Régiók Bizottsága kezdeményezte fehér könyv nem jutott magasabb döntési fórumok elé (CoR 2009; Delamartino 2009; Piattoni 2009), mint ahogy a regionális önkormányzatok európai chartáját sem sikerült az Európa Tanács tagállamaival elfogadtatni. 
Az európai szintủ politikai dokumentumokban megfogalmazott általános elvek érvényesülése eltérő közpolitikánként és országonként is. Általánosan elfogadott, hogy különösen a kohéziós politika járult hozzá a regionális reformokhoz s ezzel a decentralizációhoz Európában (Bache 1998; Bache, Andreou, Atanasova, Tomsic 2011). A regionalizmus és a regionális fejlödés között pozitív összefüggést feltételezve a régiók gazdaságfejlesztésben betöltött szerepe, versenyképességhez való hozzájárulása egyértelmủ prioritás volt a korábbi évtizedekben (Horváth 2006; Lengyel 2003). A régiók felértékelődő szerepének meghatározó pillérei voltak a partnerség és a többszintű kormányzás elvei, amelyek egyrészt arra a dilemmára válaszoltak, hogyan lehet a korlátos közösségi források mellé a gazdasági és civil szereplők forrásait, támogatását hozzárendelni, másrészt, hogyan lehet az egyes kormányzási szintek által birtokolt erőforrásokat szinergiába rendezni (Armstrong, Giordani, Macleod 2015). Természetesen a két elvnek a neoliberális „governance” paradigma, s az európai integráció mélyítésének szándéka is hátszelet biztosított, mégis azt gondoljuk, hogy a mögöttes, inkább gazdasági, hatékonysági természetű motivációk szerepe volt a döntő Nyugat-Európában, ezek mozgatták az intézményi, kormányzási átalakulást. Ugyanakkor Európa más régióiban a regionális reformok eltérő közegben zajlottak, más és más motivációk mentén.

A regionalizmus és partnerség elvei különböző mintázatokban jelennek meg az egyes regionális, de különösen nemzeti szereplők érdekei, értékei mentén. A semleges döntéshozási technikának látszó partnerség politikai eszközként is funkcionált, erőteljesen differenciálódva a konkrét politikai környezet hatására. Nem véletlen, hogy a közép- és kelet-európai országokban a partnerségnek inkább a vertikális, szintek közötti dimenziója érvényesült, s az is elsősorban külső nyomásra (Bache 2010; Piattoni 2009). A jelenség ellentmondása, hogy a regionális partnerséghez szükséges erős régiók mégsem jöttek létre, mert a felfokozott reformaktivitás csak látszólagos volt (Bouckaert 2009). Éppen arra szeretnénk rámutatni, hogy a regionalizáció nem az adott országok regionális fejlesztési lehetőségei és szükségletei mentén, hanem külsődleges elvárások hatására, mintakövetés formájában zajlott.

Mára egyértelmű, hogy a regionális decentralizáció a közép- és kelet-európai országok nagyobb részében csak rövid epizód volt. Mint ahogy kifejtjük a későbbiekben, a régiók zömmel elveszítették a szerepüket a strukturális alapok menedzselésében is. Egyre nagyobb általában is az elbizonytalanodás, hogy a regionális reformok eredményeztek-e decentralizációt, elősegítették-e a regionális kohéziót, hozzájárultak-e a régiók versenyképességéhez. Így az a kérdés is felmerül, hogy a versenyképesség az intézményi, közigazgatási térszerkezeti változásokkal mennyiben befolyásolható.

Az újabb uniós közpolitikai dokumentumokban a kormányzás jelentősége felértékelődik, ugyanakkor a regionalizmus szerepe már kevésbé hangsúlyos. Az EU2020 stratégia rögzíti, hogy a közigazgatás minősége és a versenyképesség szorosan összefügg, a tizenegy célkitűzés egyike a kormányzás minőségének ja- 
vítása. Az Európai Unió hatodik kohéziós jelentése a régiók kormányzási teljesítményére is kitér, abból kiindulva, hogy a kormányzási teljesítmény és az abszorpciós kapacitás szorosan összefügg. A jelentés megállapítja, hogy sok tagállamban nőtt a régiók önállósága (ezt a tényezőcsoportot nevezik „self-rule” indikátoroknak - Hooghe, Marks, Schakel 2008), de hangsúlyozza, hogy a válság hatására sok országban drasztikusan romlott az önkormányzatok pénzügyi helyzete és költségvetési részesedése, visszatükrözve az önkormányzatok kormányzásban elszenvedett pozícióvesztését. Az Európai Bizottság által megrendelt kutatás a régiók szintjén is mérte a kormányzási teljesítményt. Az eredmények rámutattak arra, hogy az egyes országok kormányzása regionálisan nagyon jelentős eltéréseket mutat, a régiók kormányzásának minőségi fejlesztése kihasználatlan tartalék („regional governance matters” - Charron, Lapuente, Dijkstra 2012).

Ma már tehát nagyobb az óvatosság annak megítélésében, hogy a regionalizáció képes-e a gazdaság fejlődéséhez és a területi felzárkózáshoz közvetlenül hozzájárulni. Egyrészt azért, mert sokkal árnyaltabb tudásunk van a decentralizáció állapotáról, feltételeiről és következményeiről, mint néhány évtizeddel ezelőtt, másrészt a regionalizáció trendje maga is változik, a területi decentralizáció külső körülményei átalakulnak. Hogy megértsük, vajon a hazai és általában a közép- és kelet-európai országok miért nem voltak sikeresek a regionális decentralizációban, célszerủ az elmúlt évtizedek folyamataira visszatekinteni.

\section{Kohéziós politikai ciklusok és a regionalizáció}

A regionális egyenlőtlenségek kezelése különböző közpolitikai cél- és eszközrendszert követett az elmúlt évtizedekben, más és más kormányzási kihívásokat támasztva.

Az első, felülről vezérelt (Horváth 2006), centralizált, forrás-újraelosztással operáló korszak a 2. világháború után a jóléti állam megjelenésével kezdődött. A stratégiai célokat a központi kormányzat fogalmazta meg, a helyi szervekre csupán végrehajtási funkció hárult. Tényleges fejlődés csak a centrumtérségekben zajlott le (Horváth 1998), a hatalmi szerkezet a fejlesztési pólusoknak, illetve a gazdaságilag preferált iparvidékeknek kedvezett. A helyi önkormányzatok és a kormányzat között paternalista viszony volt jellemző, a régiók önálló döntéshozási szintként nem vettek részt a fejlesztéspolitika formálásában.

A második, neoliberális, regionalizált korszak Nyugat-Európában a hetvenes-nyolcvanas évtized fordulóján következett be. A modellváltást kikényszerítette a jóléti állam erőtartalékainak kimerülése és elősegítette a gazdaságpolitikában bekövetkezett neoliberális fordulat is, amely lebontotta a központi támogatások rendszerét, versenykörülmények közé helyezve a regionális és helyi gazdaságot. Melléjük csatlakozik az EU strukturális alapjaira épülő kohéziós 
politika. A helyi gazdasági erőforrásokat is mozgósító vertikális és horizontális partnerség helyzetbe hozta a régiókat, sok országban regionális reformokat motiválva. Felértékelődik regionális és helyi szinten a politikai képviselet és az erős kormányzási (adminisztratív) kapacitás szükségessége (Roberts 1997). A regionális kormányzatok feladata a fejlesztéspolitikai képességek katalizálása, a különböző források és szereplők integrálása, a hálózatok kiépítésének segítése lett. A kilencvenes évtizedben virágzó „új regionalizmus” (Keating 2004) túlment a közgazdasági vagy kohéziós politikai hatékonyságon, új kormányzási paradigma megnyilvánulásaként fogalmazódott meg, amelyik átlépi a köz- és magánszektor szervezeti határait és a közigazgatás-földrajzi határokat (Scott 2009). Az erős regionális identitással rendelkező régiók uniós érdekérvényesítési és saját államukon belüli autonómiatörekvései kedvező fogadtatásra találtak, a régiók javára billentetve el a hatalmi viszonyokat, és hozzájárulva az uniós integráció mélyüléséhez.

A harmadik, a versenyképességre és városokra koncentráló korszak a gazdaságpolitikai orientációban bekövetkezett fordulat a lisszaboni célok nyomán bontakozik ki. A versenyképesség célja maga alá rendeli a területi, társadalmi kohéziót (Mendez 2011), s ezzel párhuzamosan a középszintű kormányzatok mellett (helyett) egyre fokozódó figyelem irányul a nagyvárosi térségekre. 2007-től a kohéziós politikai célok közé hivatalosan is bekerült a versenyképesség, ami a szegényebb régiók és országok szempontjából hátrányos következményekkel járt. Az EU kohéziós politikájának irányításában is fordulat következett be. Az ún. osztott felelősség elve alapján a 2000-ben induló programozási periódustól a tagállami kormányok erősebb kompetenciát kaptak a strukturális alapok menedzselésében az Európai Bizottság és a régiók rovására. A közép- és kelet-európai országok csatlakozása szintén a decentralizált kohéziós politikai modelltől való távolodást támogatta (Bachtler, McMaster 2008). A csatlakozó kohéziós országok régiói, a lengyel kivételtől eltekintve, nem kerültek döntéshozó pozícióba.

A jelenlegi válságkezelő, újracentralizáló korszakban a pénzügyi-gazdasági válság miatti gazdasági, társadalmi feszültségek nyomán új törekvések és szükségletek jelentek meg. Az Európai Unió 2014-ben indult új programozási periódusában megmaradt a területi különbségek kiegyenlítésének hivatalos célja, már csak azért is, mert a korábbi időszakban a területi egyenlőtlenségek, különösen az új tagállamokon belül jelentősen nőttek (1. táblázat). A gazdasági krízis elsősorban a déli és keleti perifériákat sújtotta, és jelentősen hozzájárult ahhoz, hogy a regionális polarizáció ezekben az országokban mélyült (Capello, Caragliu, Fratesi 2016; Horváth 2015).

Sok országban tovább erősödött a nemzetállami kormányzatok szerepvállalása, a helyi önkormányzatokat is sújtó költségvetési megszorításokat vezettek be, jellemzővé vált a régiók pozícióvesztése, a centralizáció. Az EU hivatalos politikája és a kohéziós politika azonban a ciklus elején még a korábbi decentralizációt támogató narratívát követte. Az EU2020 céljainak megvalósulását is 
1. táblázat: Regionális különbségek néhány kelet-európai országban az egy főre eső GDP alapján $(2000,2013)$

Regional disparities of Central and Eastern European countries (measures based on the GDP per capita), 2000, 2013

\begin{tabular}{|c|c|c|c|c|}
\hline \multirow[t]{2}{*}{ Ország } & \multirow[t]{2}{*}{ Legszegényebb régió* } & \multirow[t]{2}{*}{ Leggazdagabb régió } & \multicolumn{2}{|c|}{ Az egy före eső GDP aránya } \\
\hline & & & 2000 & 2013 \\
\hline Bulgária & $\begin{array}{l}\text { Severozapaden } \\
\text { (Yuzhen tsentralen) }\end{array}$ & Yugozapaden & 1,79 & 2,40 \\
\hline Csehország & $\begin{array}{l}\text { Severozápad } \\
\text { (Moravskoslezsko) }\end{array}$ & Praha & 2,55 & 2,79 \\
\hline Horvátország & Jadranska Hrvatska & Kontinentalna Hrvatska & 1,10 & 2,16 \\
\hline Magyarország & Észak-Magyarország & Közép-Magyarország & 2,42 & 2,72 \\
\hline Lengyelország & Lubelskie & Mazowieckie & 2,14 & 2,26 \\
\hline Románia & Nord-Est & București-Ilfov & 3,21 & 3,88 \\
\hline Szlovákia & Východné Slovensko & Bratislavský kraj & 2,88 & 3,55 \\
\hline Szlovénia & Vzhodna Slovenija & Nahodna Slovenija & 1,41 & 1,43 \\
\hline
\end{tabular}

* 2013-ban, zárójelben a 2000-ben érintett régiók.

Forrás: Eurostat 2015 adatai alapján saját számítás.

szolgáló, ugyanakkor térben differenciált szemléletű regionális politikát speciális fejlesztési sémák szolgálják (ITI, CLLD). A tervezés során még érzékelheto” „place-based” lendület (pl. S3 stratégiák) után azonban mára látszik, hogy a kohéziós források számára kialakított menedzsmentstruktúrák sok országban nem élnek a decentralizáltabb kormányzású fejlesztéspolitika lehetőségével.

\section{Kétsebességes regionális reformok a fejlett és az új európai demokráciákban}

Noha az EU kormányzási filozófiájában évtizedek óta erős hangsúlyt kapott a decentralizáció, mégis jelentős mozgástér maradt a nemzeti sajátosságok érvényesítésére. A fejlett európai demokráciákban az önkormányzatok már hagyományosan stabil gyökerekkel rendelkező részei a kormányzati rendszereknek. Ennek ellenére jelentős változások zajlottak le mind a központi-helyi hatalmi viszonyrendszerben, mind pedig a területi léptékben és szerkezetben annak érdekében, hogy a területi, helyi kormányzatok alkalmassá váljanak a növekvő feladatok befogadására. A két reformtematikát (decentralizáció és „rescaling”) a neoliberális/neokonzervatív gazdaság- és társadalomfilozófiai paradigma determinálta.

Az európai decentralizációs reformok folyamata több szakaszra tagolható (Gaulé 2010; Loughlin 2007), amelyek szoros kapcsolatban vannak a fent tárgyalt fejlesztéspolitikai ciklusokkal. Eleinte adminisztratív feladatmegosztás következik be, a központi kormányzat megőrzi a pozícióit. Majd szerkezeti, te- 
rületi reformok zajlanak, hatalmi átrendeződést eredményezve a helyi és különösen a területi/regionális önkormányzatok javára. A kormányzási reformok trendje a hierarchiától a szintek egyenlősége és a szektorok együttmüködése irányába mutatott, az uniformizált modellektől az aszimmetrikus megoldásokig évtizedeken keresztül. A neoweberi fordulatot jellemző bürokratikus és államközpontú centralizáció nem pusztán a korábbi kormányzási modellben való csalódás, hanem a gazdasági válság teremtette körülmények és az új közfeladatok terméke is (Göymen, Sazak 2014).

A területi („rescaling” - Gualini 2006) reformok Nyugat-Európában sem voltak mindig sikeresek, céljaik, következményeik is különbözőek. Bebizonyosodott, hogy a történelmi gyökereknek nagy szerepe van, és a konkrét politikai, gazdasági stb. körülmények is rendkívül változatosak, és messze nem pusztán gazdaság-, illetve fejlesztéspolitikai megfontolások mozgatják a területi kormányzatok formálását. A reformok folyamatának alaposabb elemzése rámutatott arra, hogy a konkrét hatalmi környezet nem hanyagolható el: milyen a reformokat elindító politikai vállalkozók csoportja és tudása, az intézményi környezet lehetőséget nyújt-e a részvételre és az alkudozásra (Baldersheim, Rose 2010). Különösen fontosnak bizonyult az, hogy az önkormányzatok milyen helyet foglalnak el a politikai, kormányzati rendszeren belül, ami egyébként összefüggésben van az adott ország konszenzusos vagy többségi demokráciamodelljével. Ezen a ponton érzékelhető a legjelentősebb különbség a régi és új demokráciák között: ahol az önkormányzatok hatalmi pozíciója gyengébb, ott ugyan könnyebb a drasztikus reformok végrehajtása, ugyanakkor nagyobb a tévedés veszélye, a megcélzott hatások elmaradása és a visszarendeződés is. Fontos sajátosság, hogy a régebbi demokráciákban a reformok többsége hosszabb ideig zajlott, inkább a lépésről lépésre építkezés volt jellemző. Nyugat-Európában az európai integrációs folyamat, a többszintű kormányzás modellje is hozzájárult egyes országok régióinak megerősödéséhez, viszont csak a dél-európai, majd a kelet-európai kohéziós államokban bizonyult közvetlen motivációnak az EU strukturális alapjaihoz való hozzáférés.

Összességében az állitható, hogy a fejlett demokráciák területi reformjai nem feltétlenül érintették a területi kormányzás modelljének lényegét, inkább modernizációs, korrekciós, gazdaságfejlesztési indíttatásúak voltak, kiegészülve az etnikai regionalizmus jelenségével. A területi léptékek átrendezése elsősorban belső felismerések és belső politikai motivációk mentén történt, amelyekhez képest járulékos szerepet játszott az európai integráció és különösen a kohéziós politika.

A közép- és kelet-európai országokban a területi reformok dimenziói és motivációi is eltérőek. Kétségtelen, hogy a pártállami időszakban is voltak területi reformok, kísérletek a léptékek, földrajzi határok optimalizálására, mégpedig hasonló modellek szerint, mint a fejlett nyugat-európai piacgazdaságokban. A területi reformok azonban a tanácsmodell keretei között nem járhattak valóságos decentralizációval. Az önkormányzatiságot megcélzó reformok a rend- 
szerváltással kezdődtek, külső mintát követtek a (keleti) múlttal való szakítás és a nyugathoz való felzárkózás szándékával. Közép- és Kelet-Európában a modell formálása és az optimális területi lépték kialakításának feladata időben szinte összecsúszott. A rendszerváltás - mint felfütött politikai ambíciókkal és politikai bizalmatlansággal átitatott időszak - nem kedvezett a szakmai, racionális, hatékonysági szempontokat követő törvényalkotásnak. A túl gyors és véglegesnek szánt reformok, ahogy akkortájt az aggodalom megfogalmazódott (Bennett 1994), nem kezelték külön a rendszerváltó (átmeneti) periódust, s ezzel a későbbi alkalmazkodás, a hosszú távon is alkalmas modell bevezetésének akadályaivá váltak.

A rendszerváltáson évtizedekkel túljutva látszik, hogy a közép- és kelet-európai országok nem alkotnak homogén csoportot a területi kormányzás szempontjából sem. Az okokat a szovjet birodalmi időszakot megelőző történelemben, kulturális sajátosságokban, eltérő geopolitikai kontextusban is keresik (Henderson, Pettai, Wenninger 2012; Hendriks, Loughlin, Lidström 2011; Jordan 2011), de magyarázatul szolgál a rendszerváltás utáni reformfolyamatok elemzése is.

Kétségtelen, hogy minden új közép- és kelet-európai uniós tagállam számára alapvető kihívás volt az EU strukturális és kohéziós alapjaihoz való hozzáférés, s ennek keretében a NUTS 2 régiók lehatárolása, amiben ráadásul sokkal kisebb volt a mozgástér a régi tagállamokhoz képest (Hughes, Sasse, Gordon 2004). A forrásabszorpció érdekében indított regionalizáció folyamata rámutatott arra, hogy a régióépítés nemcsak a decentralizáció és versenyképesség növelésének, hanem a centralizációnak is eszköze lehet.

A közép- és kelet-európai regionalizáció, ha úgy tetszik, megkésett és kedvezőtlen kontextusban zajlott abban az időszakban, amikor Nyugat-Európában az új regionalizmus iránti lelkesedés már jelentősen csökkent (Elias 2008). A rendszerváltás több országban a nemzetépítés folyamatával kötődött össze, ami nyilvánvalóan nehezítette a szintek közötti hatalommegosztást és az új földrajzi határok kialakítását. A rendszerváltás következtében a korábbi regionális kötődések, hálózatok is széttöredeztek, ezért a régiók kialakítása eleve nem támaszkodhatott regionális identitásra (Scott 2009). A középszintű kormányzatokkal szembeni bizalmatlanságot táplálta a kormányzat hatalomhoz való ragaszkodása és a feltételezés, miszerint a középszintek a korábbi kommunista párt fellegvárai (O’Dwyer 2006). Az új politikai elit az önkormányzatiságot a helyi szintekre korlátozta, míg riválisként kezelte a fövárosokat, nagyvárosokat és a középszintű kormányzatokat. Nem véletlen, hogy a rendszerváltás idején a helyi önállóság (vagy éppen a nemzeti identitás) védelmében nem jöttek létre erős, új középszintek. A kivételnek számító Lengyelország példája inkább erősíti a szabályt. A lengyel regionalizáció, bármennyire támaszkodott történelmi előzményekre, jellegében mégis felülről kezdeményezett volt, és inkább modernizációs, illetve fejlesztéspolitikai motivációk táplálták, semmint a regionális politikai elit törekvései (Gorzelak 2009). Lengyelországban azonban tényleges politikai akarat volt a regionalizációra, amit a történelmi tradíciók is 
támogattak, és a civil társadalom, valamint a regionális politikai elit képes volt a folyamat végigvitelére. A lengyel reformfolyamat egy idő után más közép- és kelet-európai országokhoz képest nagyobb helyi támogatottságot kapott a gyorsan kiépült regionális politikai és civil hálózatokkal, mintegy megakadályozva a visszarendeződést (Tatur 2004).

A NUTS 2-es régiók lehatárolása sem vezetett politikai, önkormányzati régiók létrehozásához Közép- és Kelet-Európában, amihez hozzájárult az Európai Unió ambivalens magatartása is, nem bízva az új régiók ,adminisztratív kapacitásaiban". Az uniós forrásokhoz való hozzáférés, az uniós elvárásrendszer teljesítésének szükségessége tehát messze nem volt elég a sikeres regionális decentralizációhoz. A középszintű kormányzatokra vonatkozó reformok az uniós csatlakozáshoz közeledve sok tekintetben „zöldmezős beruházásnak” minősültek, és nemcsak a határok megvonása, hanem a hatalom megosztásának kérdése is erős politikai konfliktusokat, ellenállást váltott (volna) ki. A felülről vezérelt régióépítés tehát lényegében a strukturális alapok fogadására szolgáló intézményrendszer kiépítésére korlátozódott.

\section{A kohéziós források fogadása a közép- és kelet-európai térségben}

A strukturális alapokból származó potenciális fejlesztési források ígérete már azelőtt elkezdte átalakítani a nemzeti tervezési és fejlesztési intézmény- és eszközrendszert Közép- és Kelet-Európában, mielőtt az előcsatlakozási, majd a strukturális és kohéziós alapok ténylegesen megnyíltak volna. Az európaizációs nyomás hatása e területen volt a legkiemelkedőbb, hiszen a strukturális és/vagy kohéziós források lehívásához szükséges nemzeti források biztosítása a kohéziós országokban lényegében ki is meríti a nemzeti fejlesztési kereteket. Ezekben az országokban gyakorlatilag nincs más jelentős fejlesztés, csak ami az uniós támogatási szisztémába beilleszthető (Mezei 2013), vagyis minden, ami megvalósul, az „európaizált” egyben. A közép- és kelet-európai térség egységes, ámde kétsebességes beemelése a tagországok közé azt is eredményezte, hogy az EU10 és EU12 fogalma bekerült a brüsszeli szakzsargonba, csoportképző eszközzé vált még olyan esetekben is, amikor az nehezen volt indokolható. Közép- és Kelet-Európa gyakorta egységes folt a strukturális politikát elemző térképeken, a területi kormányzás helyzetét vizsgáló elemzésekben vagy éppen a kedvezményezett térkategóriákat lehatároló támogatási célterületek kijelölésekor. Az EU nem volt érdekelt a belső különbségek feltárásában, hiszen az a „keleti problémát” még tovább mélyíthette volna. A place-based szemlélet tehát, amelynek érvényesülését az országok sajátosságai és a területi különbségek specialitásai egyaránt indokolták volna, nem tudott megjelenni a régió fejlesztéspolitikájában. 
Hiába rendelkezett minden ország speciális területi problémákkal, adottságokkal és feltételekkel, a kezelésükre hivatott európai strukturális politika egységes térségként kezelte a régiót és uniformizált eszközökkel próbálta eliminálni a területi különbségeket. Mindez nem gond, ha a nemzeti területi politikák egyfajta „hozzáadott értékként” néztek volna az európai uniós regionális politikára. Az európaizáció azonban dominálja a nemzeti területi politikákat, csak az uniós strukturális politikához akartak illeszkedni, csak olyan eszközöket ismertek, amelyek a strukturális alapok keretrendszerébe simultak. Elvétve akadtak olyan nemzeti vagy regionális fejlesztési tervek, amelyek nem a strukturális források lehívására születtek. Ez az erőteljes alkalmazkodási folyamat a következő főbb csomópontok mentén zajlott le:

- Minden közép- és kelet-európai ország létrehozta a saját EU-konform területfejlesztési intézmény- és eszközrendszerét. 2001-re valamennyi ország rendelkezett területfejlesztési törvénnyel (elsőként Magyarország fogadta el 1996-ban), 2006-ra pedig nemzeti regionális fejlesztési stratégiával (Horvátország későbbi csatlakozása okán 2010-re teljesítette ezeket).

- A közép- és kelet-európai országokban a területfejlesztési intézményrendszer kiépítése párhuzamosan zajlott a közigazgatási reformokkal. Akadtak országok, ahol a területfejlesztési intézmények be tudtak illeszkedni az átalakuló, megreformált közigazgatási intézményrendszerbe, máshol csak imitált közigazgatási reformok zajlottak és párhuzamos területfejlesztési intézmények épültek ki (Mezei 2016).

- A helyi, területi problémák sok esetben különleges kezelésű, kiemelten támogatott térségek lehatárolását eredményezték. Ilyen volt például a Lengyelországban 1994-től kialakított különleges gazdasági övezetek köre a strukturális válsággal küzdő ipari térségek megsegítésére (Baranyai, Lux 2014). Szlovéniában hasonló okok miatt 2009 óta külön szabályozzák az ország legelmaradottabb NUTS 3 régióját, a Muravidéket, míg Horvátországban közvetlenül a délszláv válság után hozták létre az ún. különleges kezelésű térségeket (háború sújtotta és strukturális gondokkal küzdő területek) a kiemelt állami támogatások érdekében (Mezei, Pámer 2013). Ugyanilyen különleges problémamegoldási eszközként határolták le 2007 óta Magyarországon a leghátrányosabb helyzetű 33 kistérséget, ahol speciális pályázatokat, ösztönzőket és támogatási formákat alakítottak ki. Hasonló elvek mentén lett lehatárolva 2007-től a Kelet-Lengyelország nagyrégió, amely részben európai uniós ösztönzésre az ország legfejletlenebb öt vajdaságának (Lubelskie, Podlaskie, Podkarpackie, Świętokrzyskie, Warmińsko-mazurskie) egységes kezelését célozza az európai alapok forrásainak felhasználása során.

- További speciális eszközök alkalmazására is sor került a közép- és keleteurópai országok területi problémáinak megoldása érdekében, amelyek között ott találjuk az elmaradott, speciális térségek fejlesztésére kidolgozott vagy az egész ország kiegyenlített fejlődését célzó országos regio- 
nális fejlesztési koncepciókat. Kelet-európai viszonylatban különleges a 2001 óta - francia mintára - bevezetett lengyel tervszerződések rendszere, amely keretében az állam a vajdaságokkal köt szerződéseket az állami és az európai uniós támogatások felhasználására. Elkülönült, területfejlesztési, kiegyenlítési célokra szolgáló pénzügyi alap működtetése rövidebb-hosszabb ideig megjelent például Horvátországban és Magyarországon is. Speciális területfejlesztési eszközként, elsődlegesen a külföldi működő tőke vonzása érdekében egyedi helyi adókedvezmények, vállalkozói díjkedvezmények vagy infrastruktúra-biztosítás is elöfordult több országban (pl. Szlovákia, Lengyelország, Magyarország), amelynek az EU-konform kereteit is ki kellett dolgozniuk az érintett országoknak a csatlakozás után. Sokszor ezek a kedvezmények speciális zónákhoz, ipari parkokhoz, vállalkozói vagy gazdasági övezetekhez kötődtek, amelyek kialakítása, szabályozása és támogatása szintén speciális területfejlesztési eszköznek tekinthető.

- A területfejlesztés helyzetét jól tükrözi a központi területfejlesztési irányítási rendszer kiépülése és működése. Azokban az országokban, ahol a területfejlesztésért felelős stabil minisztérium jött létre (Lengyelország, Csehország) erőteljesebb ágazatközi koordináció és a területi érdekek jobb érvényesülése a jellemző. Szlovéniában önálló, tárca nélküli miniszter felügyeli a területet és Horvátország is önálló ágazati minisztérium felállítása mellett döntött. Szlovákiában 1999-2010 között működött a regionális politikáért felelős ágazati minisztérium, míg Magyarországon utoljára 2008-2010 között volt önálló, tárca nélküli minisztere a területfejlesztésnek (Mezei 2013).

- A regionális operatív programok (ROP) elkészítése és menedzselésének módja szintén mutatja, hogy a területi szempontok, az alulról építkezés mennyire nem tudott meghonosodni az egyes országok gyakorlatában. Míg a 2004-2006-os időszakban gyakorlatilag az EU nem preferálta az elkülönült ROP-ok elkészítését (holott a régebbi tagállamokban ez volt a jellemző), a következő hét évben Szlovéniát, a periódus végén csatlakozó Horvátországot, valamint Romániát leszámítva mindenütt a NUTS 2-es régiókra is készültek önálló fejlesztési tervek. A ROP-ok megléte azonban még nem minden, hiszen Magyarországon például egységes sablonok mentén, központi, felülről vezérelt tervezéssel és az ágazati programokból kimaradó prioritásokra fókuszálva készültek el a térségi programok, amelyek menedzselése is centrális módon zajlott (Mezei 2016). Ezzel szemben Lengyelországban ténylegesen megvalósult az alulról építkezés és a ROP-ok decentralizált (vajdasági) menedzsmentje; nem véletlen, hogy éppen a lengyel területfejlesztési gyakorlatban, és csak ott tudott 2014-et követöen is továbbélni a régiókra szabott önálló ROP-ok rendszere.

A nemzeti regionális politikai intézmény- és eszközrendszer kiépítésénél kettős nyomás alatt voltak a közép- és kelet-európai országok. Egyrészről a 
csatlakozási tárgyalások fontos eleme volt az intézményrendszer EU-konformitása, vagyis az európaizáció egyfajta generális elvárásként épült be, másrészről a forrásszerzési kényszer miatt az aktuális uniós támogatáspolitikát is figyelni kellett, és a nemzeti eszköz- és intézményrendszernek készen kellett állnia annak fogadására. A két elvárásrendszer gyakran került konfliktusba egymással, és az idők során erős változáson ment át maga az európai uniós strukturális politika is (éppen a kelet-európai bővítés volt ennek a legfőbb indoka), vagyis folyamatos alkalmazkodásra (és egyre rosszabb támogatottsági pozícióba) kényszerültek a térségbeli országok.

A térségbeli növekvő polarizációra utal és a speciális kelet-európai főváros-vidék megosztottság kezelésének sikertelenségét jelzi, hogy a nagyrégiókkal müködő kis országok és Bulgária kivételével valamennyi fövárosi régió a fejlettebb térségkategóriába került a 2014-től induló programozási periódusban (1. ábra). A fokozódó térbeli differenciálódás tehát egyértelműen érzékelhető, azonban a fejletlen perifériák felzárkóztatása messze meghaladja az uniós kohéziós politika mozgásterét, ezért nem is lehet egyszerüen uniós közpolitikai kudarcként elkönyvelni a regionális különbségek mélyülését.

1. ábra: A kohéziós politika célterületei Közép- és Kelet-Európa országaiban CEE areas eligible for cohesion policy

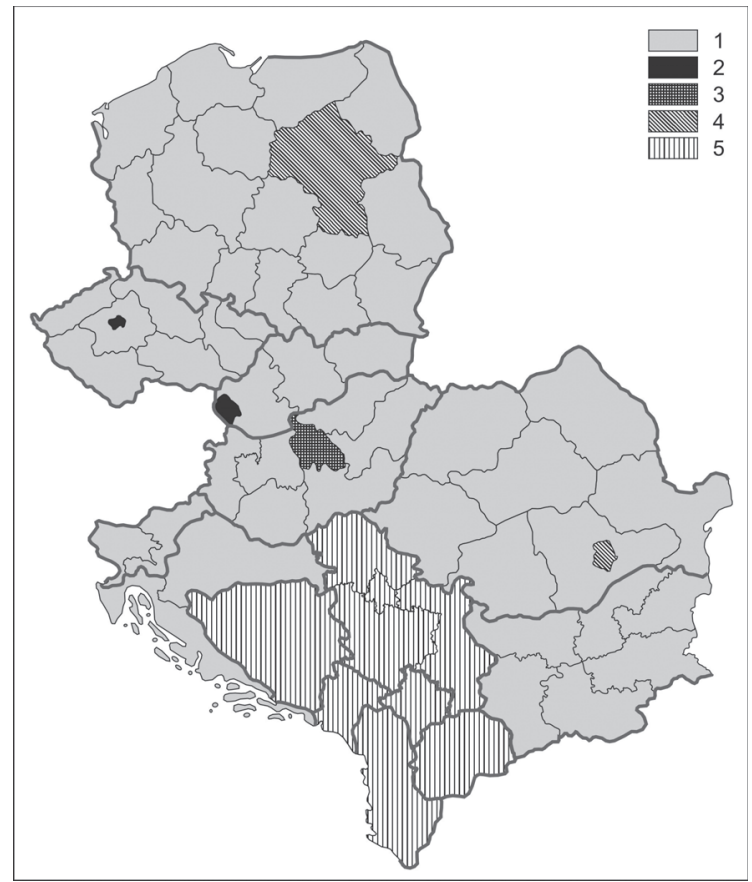

Jelmagyarázat: 1 - a csatlakozás óta konvergenciarégió; 2 - a csatlakozás óta (fejlett) versenyképességi régió; 3 - 2007-tól phasing-in, 2014-tól versenyképességi régió; 4 - 2014-tól verseny képességi régió, 5 - IPA terület. Forrás: Faragó, Mezei megjelenés alatt. 


\section{Összegzés}

Horváth Gyulának igaza volt abban, hogy az intézményi, kormányzási alkalmazkodás minőségétől jelentősen függ a regionális fejlesztés és a kohéziós politika hatékonysága, nem véletlenül törekszenek a világon mindenütt a kormányzás hatékonyságának javítására. Sajnos abban tévedett, hogy a közép- és kelet-európai új demokráciák rövid idő alatt képesek lesznek ,jól” kormányozni, s azt még ma sem lehet megválaszolni, hogy a jó kormányzás és a decentralizáció mennyiben függenek össze (Pálné Kovács 2014).

Azok az országok tudnak a leginkább a területi kormányzásban is jobb teljesítményt elérni, amelyeknek az állami, politikai kultúrája értéknek tartja a modernizációt, $\mathrm{s}$ a folyamatos változásokra tudatosan felkészíti az intézményrendszerét. A kormányzási modernizációra felkészületlen országokban erősebb a külsődleges mintakövetés, így a területi reformok hektikus és gyakran fenntarthatatlan változásokat produkálnak. Kétségtelenül relevanciája van annak is, hogy az adott ország politikai értékrendjében hol helyezkednek el az önkormányzatok (Baldersheim, Rose 2010).

Az uniós csatlakozás előtt nagyobb volt az alkalmazkodási kedv, illetve kényszer, ennek megszűnésével vált igazán világossá, hogy csak valóságos politikai szándék esetén folytatódnak a reformok (Bouckaert, Nakrošis, Nemec 2011). A közép- és kelet-európai területi önkormányzati reformok kudarcának története visszaigazolja azt is, hogy az uniformizált, külsődleges modellek átültetéseként lezajló decentralizáció többnyire nem sikeres.

Ma már egyre több hasonlóság fedezhető fel a dél-európai kormányzási rendszerek formálódásával (Pálné Kovács 2016). Európa fejletlen perifériáin elhelyezkedő, különböző időszakokban végrehajtott rendszerváltásokon átmenő mediterrán és közép- és kelet-európai posztkommunista országok állami fejlődése több megszakítottságot mutat, jelentős regionális különbségekkel küzdve. Közös kulturális sajátosságokként ismerhető fel a paternalizmus, a korrupció, az állami centralizációs hagyományok. Markánsabban tetten érhető a területi reformcélokban az általános európai (uniós) elvárások, minták követésének a szándéka vagy kényszere, miközben saját állami, politikai, regionális sajátosságaik többnyire nem kompatibilisek ezekkel.

Horváth Gyula legutolsó könyvében (2015) továbbra is hitet tett a decentralizált fejlesztéspolitika mellett, amely az EU kohéziós politikájával egyetlen kompatibilis modell. Kérdés, hogy lesz-e és milyen uniós kohéziós politika a jövőben, s annak milyen régiókkal lehet megfelelni.

\section{Köszönetnyilvánítás}

A tanulmány megjelenését az NKFIH NK 104985 számú támogatási szerződése („Új térformáló erők és fejlődési pályák Kelet-Európában a 21. század elején”) támogatta. 


\section{Irodalom}

Armstrong, H., Giordani, B., Macleod, C. (2015): The durability of European Regional Development Fund partnership and governance structures: a case study of the Scottish Highlands and Islands. Environment and Planning C, 6., 1566-1584. http://doi.org/br55

Bache, I. (1998): The politics of European Union regional policy. Sheffield Academic Press, Sheffield

Bache, I. (2010): Partnership as an EU policy instrument: A political history. West European Politics, 1., 58-74. http://doi.org/dk2djg

Bache, J., Andreou, G., Atanasova, G., Tomsic, D. (2011): Europeanization and multi-level governance in south-east Europe: the domestic impact of EU cohesion policy and pre-accession aid. Journal of European Public Policy, 1., 122-141. http://doi.org/ffvtvk

Bachtler, J., McMaster, I. (2008): EU cohesion policy and the role of the regions: investigating the influence of Structural Funds in the new member states. Government and Policy, 2., 398-427. http://doi.org/fr8bk3

Baldersheim, H., Rose, E. L. (eds.) (2010): Territorial choice. The politics of boundaries and borders. Palgrave Macmillan, Basingstoke

Baranyai, N., Lux, G. (2014): Upper Silesia: The revival of a traditional industrial region in Poland. Regional Statistics, 2., 126-144. http://doi.org/br56

Bennett, R. (ed.) (1994): Local government and market decentralization. UN University Press, Tokyo, New York, Paris

Bouckaert, G. (2009): Public sector reform in Central and Eastern Europe. Halduskultuur, 10., 94-104.

Bouckaert, G., Nakrošis, V., Nemec, J. (2011): Public administration and management reform in CEE: Main trajectories and results. The NISPAcee Journal of Public Administration and Policy, 1., 9-29. http://doi.org/bxjsnx

Capello, R., Caragliu, A,. Fratesi, U. (2016): The costs of the economic crisis: which scenario for the European regions? Environment and Planning C, 1., 13-130. http://doi.org/br57

CEMR (2013): Decentralisation at a crossroads. Territorial reforms in Europe in times of crisis. Council of European Municipalities and Regions.

Charron, N., Lapuente, V., Dijkstra, L. (2012): Regional governance matters. A study on regional variation in quality of government within the EU. DG Regional Policy, Brussels (Working Papers; 1.)

CoR, Committee of the Regions (2009): White paper on multilevel governance. Brussels

Crook, R., Manor, J. (2000): Democratic decentralisation. The World Bank, Washington (OED Working Paper Series; 11.)

Delamartino, F. (2009): The paradigm of multilevel governance. http://cor.europa.eu/en/ activities/governance/documents/277bf7de-86ea-48ce-82c1-d4310d0e2bc4.pdf (Letöltés: 2016. október 22.)

Elias, A. (2008): Introduction. Whatever happened to the Europe of Regions? Revisiting the regional dimension of European politics. Regional and Federal Studies, 5., 483-493. http://doi.org/bkwcw9

Eurostat (2015): Gross domestic product (GDP) at current market prices by NUTS 2 regions. [nama_10r_2gdp] http://appsso.eurostat.ec.europa.eu/nui/show.do (Letöltés: 2015. november 26.)

Faragó, L., Mezei, C. (megjelenés alatt): Managing regional disparities. In: Lux, G., Horváth, Gy. (eds.): The handbook to regional development in Central and Eastern Europe. Routledge, Abingdon, New York

Gaulé, E. (2010): Public governance decentralisation modelling in the context of reforms. Public Policy and Administration, 32., 47-60.

Gorzelak, G. (2009): Regional development and 'new' regionalism in Poland. In: Scott, J. W. (ed.): De-coding new regionalism. Ashgate, Aldershot, 177-198.

Göymen, K., Sazak, O. (2014): Centralization decentralization debate revisited. Istanbul Policy Center, Istanbul

Gualini, E. (2006): The rescaling of governance in Europe: New spatial and institutional rationales. Guest editorial. European Planning Studies, 7., 881-904. http://doi.org/dpvz7b

Henderson, K., Pettai, V., Wenninger, A. (eds.) (2012): Central and Eastern Europe beyond transition: Convergence and divergence in Europe. ESF, Strasbourg 
Hendriks, F., Loughlin, J., Lidström, A. (2011): Comparative reflections and conclusions. In: Loughlin, J., Hendriks, F., Lidström, A. (eds.): The Oxford Handbook of Local and Regional Democracy in Europe. Oxford University Press, Oxford, 715-742.

Hooghe, L., Marks, G., Schakel, A. (eds.) (2008): Regional authority in 42 countries, 1950-2006: A measure and five hypotheses. Regional and Federal Studies Special, 2-3.

Horváth Gy. (1998): Európai regionális politika. Dialóg Campus Kiadó, Budapest, Pécs

Horváth Gy. (2006) (szerk.): Régiók és települések versenyképessége. MTA RKK, Pécs

Horváth, Gy. (2015): Spaces and places in Central and Eastern Europe. Historical trends and perspectives. Routledge, Abingdon, New York

Hughes, J., Sasse, G., Gordon, C. (2004): Europeanization and regionalization in the EU's enlargement to Central and Eastern Europe. Palgrave Macmillan, Basingstoke

Hutchcroft, P. D. (2001): Centralization and decentralization in administration and politics: Assessing territorial dimensions of authority and power. Governance. An International Journal of Policy and Administration, 1., 23-53. http://doi.org/bcd64m

Jordan, P. (2011): Progress in administrative decentralisation in transformation countries - a comparative survey. Hrvatski Geografski Glasnik, 1., 71-85.

Kaufmann, D., Kraay, A., Mastruzzi, M. (2009): Governance matters VIII. World Bank Institute, Washington (Policy Research Working Paper; 4978.)

Kaufmann, D., Kraay, A., Mastruzzi, M. (2010): The worldwide governance indicators: Methodology and analytical issues. World Bank Institute, Washington (Policy Research Working Paper; 5430.)

Kaufmann, D., Kraay, A., Zoido-Lobatón, P. (1999): Governance matters. World Bank, Washington (Policy Research Working Paper; 2196.)

Keating, M. (ed.) (2004): Regions and regionalism in Europe. An Elgar Reference Collection, Cheltenham Lengyel I. (2003): Verseny és területi fejlődés: térségek versenyképessége Magyarországon. JATEPress, Szeged

Litvack, J., Ahmad, J., Bird, R. (1998): Rethinking decentralization in developing countries. World Bank, Washington (Sector Studies Series) http://doi.org/cmsgh5

Loughlin, J. (2007): Reconfiguring the state: Trends in territorial governance in European states. Regional and Federal Studies, 4., 385-403. (Special Issue: Contemporary Trends in Territorial Governance) http://doi.org/cj25qh

Manor, J. (1999): The political economy of democratic decentralization. World Bank, Washington http://doi.org/fc85rx

Marcou, G. (2008): Postface. Essay on the clarification of some key concepts and methodological problems. In: Decentralisation and local democracy in the world. First UCLG Global Report. The World Bank, Barcelona, 305-313.

Mendez, C. (2011): The Lisbonization of EU cohesion policy: A successful case of experimentalist governance? European Planning Studies, 3., 519-537. http://doi.org/c22gbn

Mezei, C. (2013): Case study report. Building Structural Fund management systems: Learning by doing or imitating? In: ESPON TANGO - Territorial Approaches for New Governance: Annex A: Case Studies. ESPON, Luxemburg, Final version. 91-110. http://www.espon.eu/export/sites/ default/Documents/Projects/AppliedResearch/TANGO/

ESPON_TANGO_Case_Study_Annex_A_final.pdf (Letöltés: 2016. február 25.)

Mezei, C. (2016): Limited involvement: the role of local and regional actors in the Hungarian Structural Fund management. In: Schmitt P., Well, L. V. (eds.): Territorial governance across Europe: Pathways, practices and prospects. Routledge, London, New York, 157-170.

Mezei C., Pámer Z. (2013): Területfejlesztés és intézményrendszere. In: Hajdú Z., Nagy I. (szerk.): DélPannónia. MTA KRTK Regionális Kutatások Intézete, Dialóg Campus Kiadó, Pécs, Budapest, 430-455.

O'Dwyer, C. (2006): Reforming regional governance in East Central Europe. Europeanization or domestic politics as usual? East European Politics and Societies, 2., 219-253. http://doi.org/dd9x3x

Pálné Kovács I. (2014): Jó kormányzás és decentralizáció. MTA, Budapest

Pálné Kovács I. (szerk.) (2016): A decentralizáció magyar kudarca nyomában. Dialóg Campus Kiadó, Budapest, Pécs

Piattoni, S. (2009): Multi-level governance in the EU. Does it work? Globalisation and Politics. MIT. http://www.princeton.edu 
Roberts, P. (1997): Sustainability and spatial competence: an examination of the evolution, ephemeral nature, and possible future development planning in Britain. In: Danson, M. (ed.): Regional governance and economic development. European research in regional science. Pion, London, 7-26.

Scott, J. W. (ed.) (2009): De-coding new regionalism. Ashgate, Aldershot

Stead, D., Nadin, V. (2011): Shifts in territorial governance and the Europeanisation of spatial planning in Central and Eastern Europe. In: Adams, N., Nunes, R. (eds.): Territorial development, cohesion and spatial planning. Routledge, London, New York, 154-178.

Tatur, M. (ed.) (2004): The making of regions in post-socialist Europe - the impact of culture, economic structure and institutions. VS Verlag für Sozialwissenschaften, Wiesbaden

Treisman, D. (2002): Defining and measuring of decentralisation. A global perspective. University of California, Los Angeles 